\title{
Aspects of agricultural use of potato starch waste water
}

\author{
F. A. M. de $\operatorname{Haan}^{1}$, G. J. Hoogeveen ${ }^{2}$ and F. Riem Vis ${ }^{3}$ \\ 1 Laboratory of Soils and Fertilizers, Agricultural University, and Institute for Land and \\ Water Management Research, Wageningen, the Netherlands \\ 2 Government Service for Land and Water Use, Utrecht, the Netherlands \\ 3 Institute for Soil Fertility, Haren, the Netherlands
}

Accepted: 24 January 1973

\section{Summary}

Agricultural industries in the northeastern part of the Netherlands, with the potato starch industry as the most important one, produce a very large amount of waste water. Research work is now performed on possible solutions to the environmental problems resulting from discharge of this water on open canals. Land disposal offers such a possibility. Since the waste water contains the natural components of potatoes only it can be considered as a relatively innocent type of industrial waste water. Moreover, the main constituents are also the major elements for plant nutrition thus rendering an opportunity to recycle these components.

Evaluation of waste water utilization for agricultural purposes must be based on a number of criteria of which the most important ones are: purification by the soil system, fertilization of agricultural crops, and economic effects for the farmer whose land is used for this kind of waste water treatment. In the economic evaluation with respect to other proposed solutions, cost of application is also to be taken into account.

This article is confined to the three first-mentioned criteria. Experimental results and model calculations indicate that with mean yearly application rates in the range of 50 to $100 \mathrm{~mm}$ the relevant requirements can be met at a farmers profit of about 100 guilders per ha.

\section{Introduction}

The potato starch industry in the Netherlands is concentrated in the northeastern part of the country, known as the Peat Colonies. By application of the latest methods for land desinfection almost $50 \%$ of the agricultural land in this area is now yearly utilized for the production of starch potatoes. The starch is extracted in some thirteen factories spread over the area. This starch production gives a tremendous amount of waste water with a total waste burden comparable to about 22 million human equivalents on the basis of biochemical oxygen demand (BOD). The waste water is released on open canals and water ways thus giving rise to highly undesirable environmental conditions in the area.

Possible solutions for this waste water problem are studied by a number of research institutes working jointly in especially created working groups, whereas the potato starch industry itself strives for a limination of water use during the starch extraction procedure, and carries out research on means for protein recovery from the resulting concentrated waste water. Evaluation of the proposed solutions will be performed by a special Steering 
Committee (Kronenberg, 1972).

This article describes several aspects of land disposal, combined with agricultural use of the nutrient elements present in the waste water. Such a combination is necessitated by the limited purifying capacity of soil, thus rendering land disposal of the waste water in excessive amounts impossible. Moreover, the waste water represents a large value of fertilizing constituents, whereas utilization of these elements in plant production may possibly lead to a high degree of recirculation. In this respect the main aspects discussed here are the degree of purification by the soil, the agricultural utilization of the nutrient elements and the consequences from a farm economic point of view.

Two types of waste water result from starch production, viz the wash and transport water, and the process water. The first-mentioned type usually leaves the factory in a separate flow. Its contribution to the total waste production amounts to only $5 \%$. Since it may contain germs it is supposed to be less suitable for agricultural utilization, although some indications were found that a mixing of both types of waste water possibly may make the germs harmless. Here the wash and transport water is left out of consideration.

The process water results from the extraction and refinery of the starch from potatoes. The amount that is produced may differ from one factory to the other, depending on the means of extraction and starch washing procedure, and has a mean value of about $8 \mathrm{~m}^{3}$ per ton $(1000 \mathrm{~kg})$ of potatoes. At the present capacity of the combined factories this implies a total yearly processing water production of about 20.5 million $\mathrm{m}^{3}$. A tendency exists to decrease the waste water production, e.g. by applying a partial or complete washing with an 'against the stream' procedure.

Potato starch process water contains, with the exclusion of starch, the components of potatoes in a diluted form. In view of the above it will be clear that the actual composition may show a wide variation. On the basis of mean starch potato composition one should expect $3.5 \mathrm{~kg} \mathrm{~N}, 0.9 \mathrm{~kg} \mathrm{P}_{2} \mathrm{O}_{5}$ and $5 \mathrm{~kg} \mathrm{~K} \mathrm{~K}_{2} \mathrm{O}$ per ton of potatoes. A large number of waste water analyses showed the ratio between the concentrations of nitrogen, phosphate and potassium to be on an average of $\mathrm{N}: \mathrm{P}_{2} \mathrm{O}_{5}: \mathrm{K}_{2} \mathrm{O}=1: 0.36: 1.8$. Nitrogen predominantly occurs as proteins, amino acids and $\mathrm{NH}_{4}$. Phosphorus is present as orthophosphates and to a minor degree as polyphosphates.

\section{Purification by the soil system}

In a number of experiments the purification of process water after application to soils was studied by a comparison of the composition of the upper groundwater and the waste water added (de Haan, 1972; de Haan and Beuving, 1972). The degree of purification was found to be strongly dependent on soil properties and on external conditions, such as amounts applied and concentration of the waste water. Table 1 gives mean data of the composition of waste water added to sandy and peaty soils in amounts of $500 \mathrm{~mm}$ by means of flooding. Also the mean composition of the upper $50 \mathrm{~cm}$ layer of groundwater on both types of soil profiles is presented as well as the groundwater composition on comparable untreated plots and analysis data of groundwater samples taken at a depth of 60 meters below floodfields. These floodfields have been used over already 40 years for yearly applications of about $500 \mathrm{~mm}$ potato starch process water.

With respect to the removal of the major elements $\mathbf{N}, \mathbf{P}$ and $\mathrm{K}$, from the waste water, different reaction mechanisms in the soil-water system contribute to the purification. The phosphate and potassium reactions are relatively simple and mainly concern precipitation and adsorption reactions. Nitrogen reactions are of a more complicated nature since they 
Table 1. Composition (in $\mathrm{mg} / \mathrm{l}$ ) of applied process water, the upper $50 \mathrm{~cm}$ groundwater in sandy and peaty soils and untreated plots, and groundwater under floodfields sampled at a depth of $60 \mathrm{~m}$.

\begin{tabular}{|c|c|c|c|c|c|c|c|c|c|}
\hline & COD & $\mathrm{BOD}_{5}$ & $\mathrm{~N}$-total & $\begin{array}{l}\mathrm{NH}_{4} \\
\text { inorganic }\end{array}$ & $\begin{array}{l}\mathrm{NH}_{4} \\
\text { organic }\end{array}$ & $\mathrm{NO}_{2}$ & $\mathrm{NO}_{3}$ & $\mathrm{PO}_{4}$ & $\mathrm{~K}$ \\
\hline Waste water & 8400 & 3900 & 420 & 100 & 310 & - & 5 & 190 & 580 \\
\hline $\begin{array}{l}\text { Groundwater } \\
\text { on sandy soil }\end{array}$ & 320 & 34 & 18 & 14 & 5.8 & 1.6 & 61 & 1.1 & 197 \\
\hline $\begin{array}{l}\text { Groundwater } \\
\text { on peaty soil } \\
\text { Groundwater }\end{array}$ & 680 & 46 & 36 & 24 & 10 & 1.0 & 25 & 47 & 251 \\
\hline $\begin{array}{l}\text { on untreated } \\
\text { sandy soil } \\
\text { Groundwater }\end{array}$ & 56 & 2 & 2.3 & 1.0 & 1.6 & 0.2 & 17 & 0.3 & 15 \\
\hline $\begin{array}{l}\text { at } 60 \mathrm{~m} \text { beneath } \\
\text { floodfields }\end{array}$ & 60 & & 1.0 & 0.9 & 0.1 & & & 0.8 & \\
\hline
\end{tabular}

involve a combination of microbiological and adsorption processes which may occur simultaneously or subsequently. If present as $\mathrm{NH}_{4}{ }^{+}$, nitrogen may be adsorbed on the soil complex. The organic nitrogen compounds are decomposed by microbiological activity, leaving as final products $\mathrm{C}, \mathrm{H}, \mathrm{O}$ and $\mathrm{NH}_{4}{ }^{+}$. Biological decomposition is favoured by aerobic conditions. If such conditions prevail ammonium may easily be transformed to nitrate by nitrification, thus enabling nitrate leaching by surplus water. If anaerobic conditions occur denitrification will take care of part of the nitrate which is transformed to gaseous nitrogen compounds, thus leaving the soil system by volatilization.

The data of Table 1 show a high degree of relative purification of waste water, i.e. removal of constituents is extremely high if expressed as percentage of the original waste water content. However, concentrations of all components in the groundwater have increased after application, as compared to the groundwater of untreated plots. A marked difference was found between sandy and peaty profiles, in favour of sandy soils. With respect to the decrease of oxygen demand, reaction conditions in the sandy soil have apparently been slightly better than in peat. As a result of more aerobic conditions the nitrate concentration is also higher in sand. Phosphate removal in the soils used must mainly be attributed to precipitation as iron and/or aluminium phosphates whereas chemisorption may play a minor role only. In this respect the almost complete absence of phosphate in the groundwater of sandy soils is plausible; groundwater of the peaty profiles shows a high phosphate concentration. In both soil types potassium is removed to a minor degree only, as a result of the very limited adsorption capacity. Analyses data of deep groundwater indicate that no influence seems to be present at this depth.

In the first days after application a break-through of the soil filter was found at all sampling points, sampling data showing $\mathrm{BOD}_{5}$ values up to 1000 . A gradual decrease of the oxygen demand was measured during the first weeks after application.

In a separate flooding experiment the influence was studied of partial additions of a total dose of $520 \mathrm{~mm}$ with time intervals of three weeks resulting in a complete purification of $140 \mathrm{~mm}$ applicated, whereas between the second and third dose of $140 \mathrm{~mm}$ a sharp increase of the oxygen demand of groundwater was found. From a viewpoint of purification doses should not exceed the water storage capacity of the soil, thus maintaining favourable conditions for biological decomposition. In this respect sprinkling irrigation is a better technique of application than flooding as small doses can than be regulated much more accurately. 


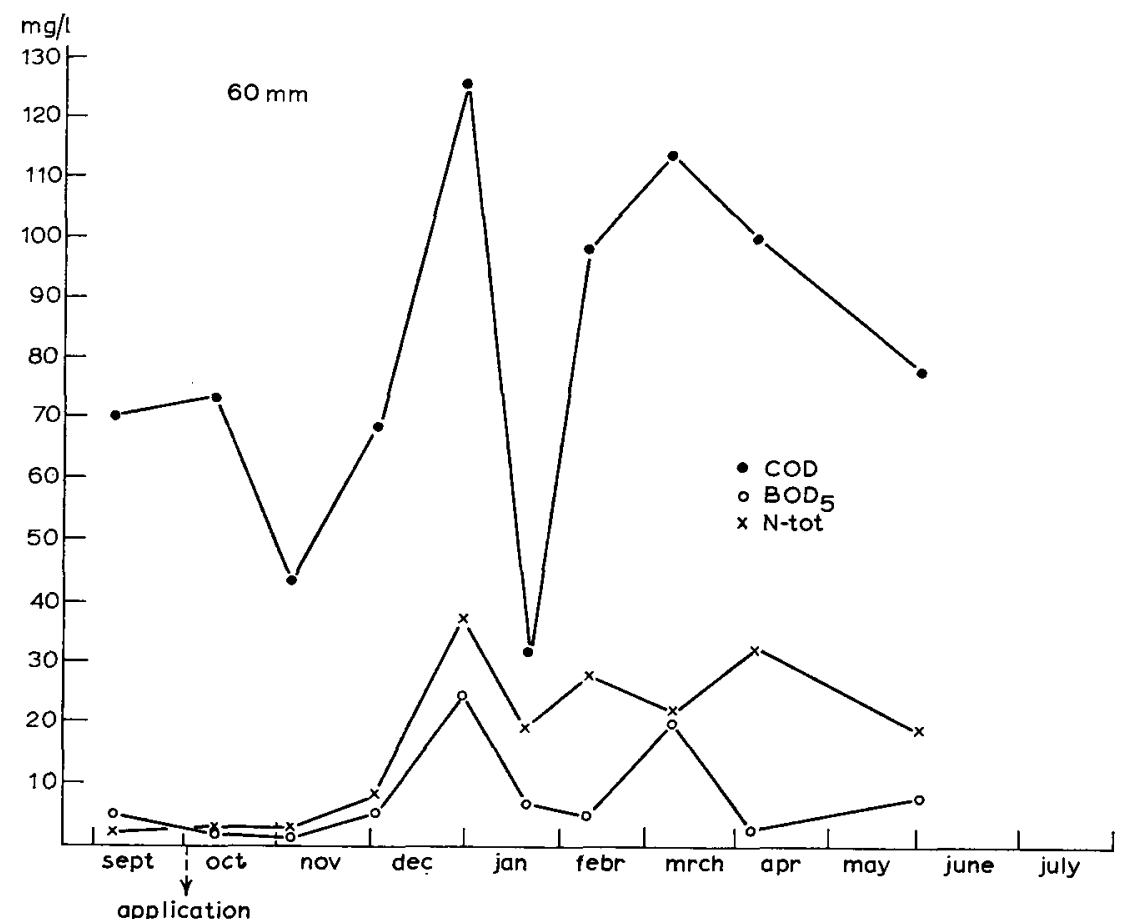

Fig. 1. Course of chemical oxygen demand (COD), biochemical oxygen demand (BOD) and total nitrogen content (N-total) of the upper groundwater before and after $60 \mathrm{~mm}$ potato starch process water application.

Sprinkling irrigation of process water was applied on a sandy soil. The concentration of this waste water slightly differed from the mean composition; the application rate was chosen in such a way that the waste burden equalled $60 \mathrm{~mm}$ of mean process water. Fig. 1 shows the course of $\mathrm{COD}, \mathrm{BOD}_{5}$ and N-total values of the upper groundwater before and after waste water addition. At the end of December and the beginning of February heavy rainfall still caused a small leaching of organic matter. Here also groundwater composition gradually improved after leaching.

Much more research work has to be done for a correct understanding of the reactions in the soil system following the disposal of waste water and the ways in which these reactions can be influenced. Nevertheless it may be concluded from the given data that good purification is obtained if yearly applications do not exceed 100 to $150 \mathrm{~mm}$, preferably applied in partial doses of for instance 40 to $50 \mathrm{~mm}$. As has been proved by the sandy soils used in the experiments, a high degree to phosphate removal can last for a time period of at least some 40 years.

\section{Utilization of plant nutrient elements}

As was stipulated above, utilization of plant nutrient elements from the process water should be preferred from both an economic and environmental point of view. Fortunately 
Table 2. Relative efficiency index for nitrogen, phosphorus and potassium from potato starch process water of average composition.

\begin{tabular}{llll}
\hline Crop & $\mathrm{N}$ & $\mathrm{P}_{2} \mathrm{O}_{5}$ & $\mathrm{~K}_{2} \mathrm{O}$ \\
Potatoes & 0.5 & 0.5 & 0.8 \\
Beets & 0.5 & 0.5 & 0.8 \\
Cereals & 0.2 & 0.5 & 0.4 \\
Grass & 0.8 & 0.5 & 0.8 \\
\hline
\end{tabular}

the main constituents of this water are at the same time the major fertilizing elements for agricultural crop production. Applications must then be adjusted in such a way that in addition to purification requirements also plant nutrient requirements are met. For a correct adjustment with respect to the second condition, the availability for plant nutrition of waste water constituents must be known. This availability is expressed by means of a so-called relative efficiency index for the different elements, being the ratio between the amount of a certain element available from fertilizer application and the amount available from waste water disposal, giving the same element supply for crop growth. As a measure of comparison, one may choose the amount of the element taken up by the crop or the crop yield. Relative efficiency indices have to be determined experimentally for different crops and nutrient elements in experiments under field conditions (Kortleven, 1968; Riem Vis, 1971a).

Table 2 gives the efficiency indices for several agricultural crops and the three major nutrient elements when process water of mean composition is used.

As the efficiency indices have been estimated from the results of a relative small number of experiments, relationships between fertilization and crop yield were used to predict the influence of large quantities of waste water on crop yield and/or quality. Adjustment of water application can be based on several criteria, viz optimal adjustment to plant requirements, and excess of optimal supply which may or may not result in harmful effects.

\section{Optimum adjustment to plant requirements}

The ratio between the concentration of the nutrient elements in the waste water, and (due to differences in relative efficiency indices) the availabilities to corps, differs from the ratio required for optimum plant growth. As a result of the high K-content of the waste water, this actually means that optimum adjustment usually must be based on potassium supply. Additional supply of nitrogen and phosphate fertilizer must then meet the plant requirements for these elements.

In Table 3 an example of a fertilization scheme is presented, based upon the adjustment of water application to the potassium requirements of several crops.

Such an adjustment, however, would lead to a very large area of agricultural land required for disposal of all the waste water. With the assumption that $50 \%$ of the area is covered by potatoes, as actually is the situation in the Peat Colonies, and the other crops mentioned in Table 3 equally distributed over the remaining area, it follows from this table that the mean value for optimum adjustment would amount to $25 \mathrm{~mm}$ per year. In view of the total waste water production, 82000 ha of agricultural land would be needed for land disposal according to the criterion of optimum adjustment.

Cost for application of waste water very strongly increases with decreasing amounts 
Table 3. Scheme of fertization, based on potassium requirements, with potato starch process water with contents of $390 \mathrm{mg} \mathrm{N}, 140 \mathrm{mg} \mathrm{P}_{2} \mathrm{O}_{5}$ and $700 \mathrm{mg} \mathrm{K} \mathrm{K}_{2} \mathrm{O}$ per litre.

\begin{tabular}{|c|c|c|c|c|c|c|c|}
\hline \multirow[t]{2}{*}{ Crop } & \multirow[t]{2}{*}{$\begin{array}{l}\text { Recommended } \\
\text { potassium supply } \\
\text { in } \mathrm{kg} \mathrm{K}_{2} \mathrm{O} / \mathrm{ha}\end{array}$} & \multirow{2}{*}{$\begin{array}{l}\text { Relative } \\
\text { efficiency } \\
\text { index for } \\
\mathrm{K}_{2} \mathrm{O}\end{array}$} & \multirow{2}{*}{$\begin{array}{l}\text { Required } \\
\text { amount of } \\
\text { waste water } \\
\text { in } \mathrm{mm}\end{array}$} & \multicolumn{2}{|c|}{$\begin{array}{l}\text { Available from } \\
\text { waste water } \\
\text { in } \mathrm{kg} / \mathrm{ha}\end{array}$} & \multicolumn{2}{|c|}{$\begin{array}{l}\text { Additional } \\
\text { fertilizer supply } \\
\text { in } \mathrm{kg} / \mathrm{ha}\end{array}$} \\
\hline & & & & $\mathbf{N}$ & $\mathrm{P}_{2} \mathrm{O}_{5}$ & $\mathbf{N}$ & $\mathrm{P}_{2} \mathrm{O}_{5}$ \\
\hline Potatoes & 100 & 0.8 & 18 & 35 & 12 & 145 & 88 \\
\hline Sugar-beets & 150 & 0.8 & 27 & 52 & 19 & 128 & 61 \\
\hline Cereals & 80 & 0.4 & 28 & 22 & 12 & 78 & 18 \\
\hline Grass & 160 & 0.8 & 29 & 90 & 33 & 160 & 27 \\
\hline Silage corn & 300 & 0.8 & 54 & 168 & 60 & 32 & 40 \\
\hline
\end{tabular}

per unit of area (Baars, 1972). Thus from an economic point of view optimum adjustment must possibly be abandoned. In that case the decrease in cost for application has to be compared with the resulting depressions in yield or quality. Non-optimum adjustment, however, does not necessarily result in depressions.

\section{Excess of application without harmful effects}

Such an excess implies an overdose of one or more nutrient elements, not resulting in a depression of yield or quality of the agricultural products. Overdosing usually increases risks in crop production. As a result of excess nitrogen, sugar contents of beets may decrease and lodging of cereals may induce depressions in yields of grains and straw. Excess of potassium decreases the starch content of potatoes and influences the extractibility of sugar from beets unfavourably. Grass tetany may be induced by an unfavourable mineral composition of grass. The result of an overdose can be estimated by using relationships between nutrient supply and yield and/or quality. For a number of crops such relationships are presented in Fig. 2.

In general it can be stated that risks induced by nutrient overdoses are eliminated or strongly limited if the following measures are taken with respect to the adjustment of nutrient supply: for cereals based on nitrogen requirements; for potatoes based on potassium requirements; for sugar-beets based on potassium requirements if payment is based on purity of sap, on nitrogen requirements if payment is based on sugar content; with respect to grass additional magnesium must be supplied to cattle, whereas extremely large applications of waste water should be avoided in view of possible nitrate poisening of cattle (Riem Vis, 1971b).

In a similar way as was done above a fertilization scheme can be arranged on the basis of harmless overdoses. Then the data of Table 4 are found. Assuming the same crop distribution over the agricultural area was as given above one now arrives at a mean yearly application rate of $60 \mathrm{~mm}$, thus requiring a total area of $33000 \mathrm{ha}$.

\section{Excess of application with harmful effects}

An increase of waste water application above a certain limit will undoubtedly decrease crop production whether in yield or in quality. From a viewpoint of fertilization such applications are objectionable. Whether it is acceptable from an economic point of view or not depends of the economic effect of yield decrease as against, for instance, further savings in fertilizer and in application cost. The influence on farm economic results will be discussed in the next section. 
STARCH POTATOES

decrease of yield

payment weight, $\mathrm{kg} /$ are

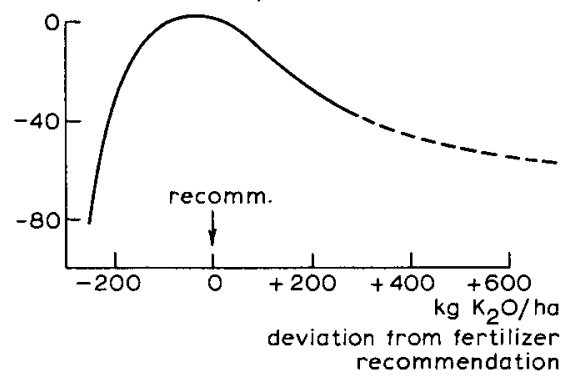

CEREALS

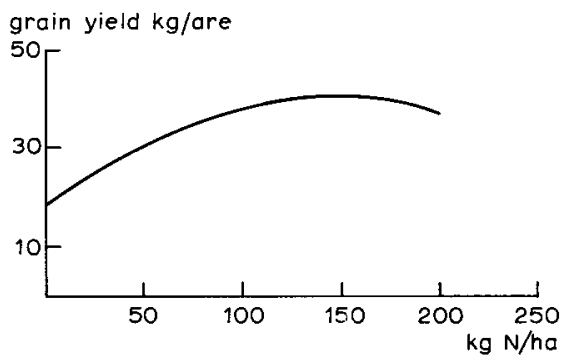

GRASSLAND

annual production airdry grass $\mathrm{kg} /$ are

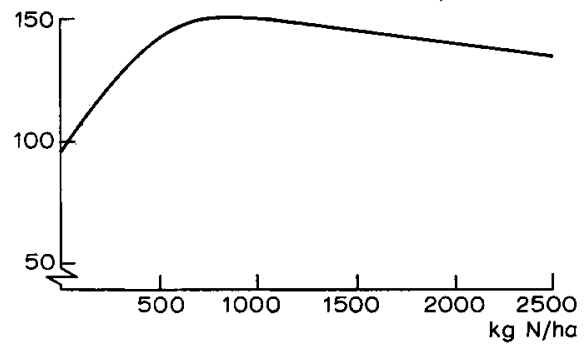

SUGAR BEET

decrease of yield $\mathrm{kg}$ of sugar/are

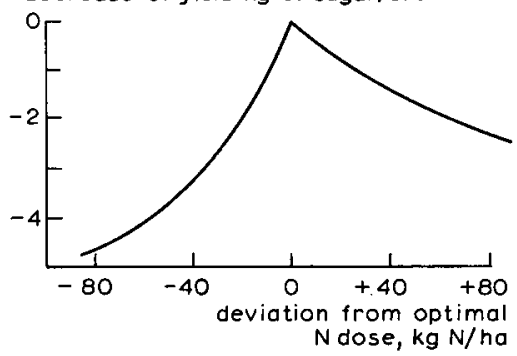

source: 1.8 .

Fig. 2. Influence of fertilizer supply on yield of several agricultural crops.

Especially if applications are higher than required attention must be paid to possible enrichment of the soil which might lead to long-term effects with respect to crop production. As a result of preliminary investigations (Anonymous, 1972) it was found that undesirable changes in fertility status of the soil are not to be expected, although an increase of available potassium might influence starch production. In view of a decrease of soil $\mathrm{pH}$, attention must be paid to additional liming. If large amounts of waste water are frequently applied a decrease in water permeability might result due to blocking of soil pores by organic matter.

Table 4. Fertilization scheme based on harmless overfertilization with potato starch process water with contents of $390 \mathrm{mg} \mathrm{N}, 140 \mathrm{mg}_{2} \mathrm{O}_{5}$ and $700 \mathrm{mg} \mathrm{K} 2 \mathrm{O}$ per litre.

\begin{tabular}{|c|c|c|c|c|c|c|c|c|c|}
\hline \multirow[t]{2}{*}{ Crop } & \multicolumn{2}{|c|}{$\begin{array}{l}\text { Recommended } \\
\text { supply } \\
\text { in } \mathrm{kg} / \mathrm{ha}\end{array}$} & \multirow{2}{*}{$\begin{array}{l}\text { Required } \\
\text { amount of } \\
\text { waste water } \\
\text { in } \mathrm{mm}\end{array}$} & \multicolumn{3}{|c|}{$\begin{array}{l}\text { Available from } \\
\text { waste water } \\
\text { in } \mathrm{kg} / \mathrm{ha}\end{array}$} & \multicolumn{3}{|c|}{$\begin{array}{l}\text { Additional fertilizer } \\
\text { supply } \\
\text { in } \mathrm{kg} / \mathrm{ha}\end{array}$} \\
\hline & $\mathbf{N}$ & $\mathrm{K}_{2} \mathrm{O}$ & & $\mathbf{N}$ & $\mathrm{P}_{2} \mathrm{O}_{5}$ & $\mathrm{~K}_{2} \mathrm{O}$ & $\mathrm{N}$ & $\mathrm{P}_{2} \mathrm{O}_{5}$ & $\mathrm{~K}_{2} \mathrm{O}$ \\
\hline Potatoes & - & 150 & 27 & 53 & 19 & 150 & 127 & 81 & - \\
\hline Sugar-beets & - & 300 & 54 & 105 & 38 & 30 & 75 & 42 & - \\
\hline Cereals & 100 & - & 128 & 100 & 54 & 358 & - & - & - \\
\hline Grass & 300 & - & 96 & 300 & 107 & 537 & - & - & - \\
\hline Silage corn & 300 & - & 96 & 300 & 107 & 537 & - & - & - \\
\hline
\end{tabular}




\section{Farm economic results of waste water application}

The influence of waste water utilization on farm economic results was investigated by means of a computarized model study. Cattle farming was left out of consideration for a number of reasons, of which the most important one is that no expansion of cattle breeding is to be expected in the Peat Colonies in the near future.

In this model study a number of boundary conditions was introduced, adjusted to the actual situation in this area (Hoogeveen, 1972). The model was then defined as a farm exploitation system in which the farmer strives for the highest possible economic net result. This result is expressed as yearly labour income. Obviously waste water application influences farm exploitation in several ways. On the one hand savings in cost for fertilizers can be calculated for all rates of application. On the other hand, yield depressions as a consequence of non-optimum meeting of nutrient requirements and application rates must also be taken into account. Moreover, the farmer experiences disadvantages as the water has to be disposed of in fall when there is no need for additional water and the disposal may force a delay in farm operations. All these and related factors were evaluated. In this model study cost of application is left out of consideration.

The following boundary conditions are mentioned here:

- mean area of parcels amounts to $3.2 \mathrm{ha}$, at an average distance of $1500 \mathrm{~m}$ from the farm buildings (Reinds, 1971);

- discharge of artificially applied water, in addition to natural rainfall, must be performed within 30 days after application;

- the maximum yearly manhours per man amount to 2250 hours, divided over fortnight periods with a maximum of 130 hours per period; limitations in time for fieldwork caused by climatic conditions were also taken into account;

- maximum values of crop coverage per holding are: $50 \%$ for starch potatoes; $25 \%$ for sugar-beets; $80 \%$ for cereals; $10 \%$ for cannery peas; $10 \%$ for grass and $10 \%$ for silage corn;

- prices are calculated according to data from the Agricultural Economic Institute (LEI) at the level 1970/1971.

The different models used in the calculation of which results are presented here were: I: one-man holdings with an area of 25 and 50 ha, and the optimum holding area at this labour supply including partial contractors' work;

Tabel 5. Yearly labour income per holding (Dutch guilders) at different doses of potato starch process water.

\begin{tabular}{|c|c|c|c|c|c|c|}
\hline \multirow{3}{*}{$\begin{array}{l}\text { Dose } \\
\text { in } \mathrm{mm}\end{array}$} & \multicolumn{3}{|l|}{ Model I } & \multicolumn{3}{|l|}{ Model II } \\
\hline & \multirow{2}{*}{$\begin{array}{l}\text { income } \\
\text { at } 25 \text { ha }\end{array}$} & \multicolumn{2}{|c|}{ optimum area } & \multirow{2}{*}{$\begin{array}{l}\text { income } \\
\text { at } 75 \text { ha }\end{array}$} & \multicolumn{2}{|c|}{ optimum area } \\
\hline & & ha & income & & ha & income \\
\hline 0 & 9614 & 47 & $\begin{array}{ll}20 & 191\end{array}$ & 26923 & 78 & 27960 \\
\hline 50 & 12296 & 49 & 25412 & 34641 & 99 & 40351 \\
\hline 100 & 12197 & 49 & 25417 & 33970 & 96 & 39395 \\
\hline 150 & 11666 & 48 & $22 \quad 139$ & 32376 & 92 & 36796 \\
\hline 200 & 10789 & 46 & 17559 & 29955 & 93 & 34257 \\
\hline 300 & 6205 & 26 & 6836 & -* & 70 & 16532 \\
\hline
\end{tabular}

* Non-computable within the boundary conditions introduced. 
II : two-man holdings with an area of $25,50,75$ and 100 ha and the optimum holding area at this labour supply including partial contractors' work.

Farm results were calculated without waste water utilization and with utilization at applications of 50,100, 150, 200 and $300 \mathrm{~mm}$ per year. These are mean values per holding; as was shown above some crops are more sensitive than others, thus optimizing of distribution of applications over the different crops was introduced (except for the $300 \mathrm{~mm}$ dose). Presentation of the results is here confined to the most relevant holding models, viz I with 25 ha and optimum area, and II with 75 ha and optimum area. The influence of doses on yearly labour income is given in Table 5 .

At low applications a considerable increase of labour income is found in comparison to zero doses. This is for the major part caused by savings in cost for fertilizers. Higher doses induce a decrease caused by depressions in yield and quality, and by peaks of work in springtime. The strong decrease at the $300 \mathrm{~mm}$ dose is inacceptable so this dose was left out of further consideration.

Naturally the labour income per holding is, aside from waste water utilization, strongly dependent on holding area. Expression of the increase in income per unit surface area, however, leads to an interesting conclusion (see Table 6).

Thus it is found that mean applications per holding of 50 and $100 \mathrm{~mm}$ result in the highest increase in labour income per ha. Here the effect is almost the same for both models at 25 and 75 ha, respectively, and at the optimum holding areas. These doses are at the level of harmless excess of nutrient supply, as was discussed above. At higher applications holding area does influence the change of labour income per ha. As a general conclusion it can be stated that a mean increase in labour income of 100 guilders per ha is obtained, independent from holding area, if the dose does not exceed $100 \mathrm{~mm}$ per year.

These values are required for a final economic evaluation of process water utilization in which cost of application is to be compared with farm economic advantages (Anonymous, 1972). Although such an evaluation is beyond the scope of this paper it can be mentioned that land disposal of potato starch process water offers a good opportunity to solve this typical waste water problem. Final cost does not exceed 5 guilders per ton of potatoes.

\section{Conclusions}

Land disposal of potato starch process water results in a very high degree of purification, even at high application rates. Complete purification is obtained in sandy soils if the rates do not exceed 100 to $150 \mathrm{~mm}$ per year. To maintain favourable conditions for biological decomposition of the organic matter the dose should be less than the water storage capacity of the soil. This can best be effected by partial application of the yearly dose if waste

Table 6. Increase of yearly labour income per ha (Dutch guilders) by waste water utilization at different doses for different models

\begin{tabular}{llllll}
\hline $\begin{array}{l}\text { Dose } \\
\text { in } \mathrm{mm}\end{array}$ & \multicolumn{2}{l}{ Model I } & & \multicolumn{2}{l}{ Model II } \\
\cline { 2 - 3 } \cline { 5 - 6 } & 25 ha & optimum area & & 75 ha & optimum area \\
50 & 107 & 107 & & \\
100 & 103 & 107 & 93 & 125 \\
150 & 82 & 41 & 73 & 119 \\
200 & 47 & -58 & 40 & 68 \\
\hline
\end{tabular}


water of mean composition has to be disposed of. To this purpose sprinkling irrigation must be preferred to flooding. At comparable waste burdens purification requirements can easier be met at higher waste water concentrations.

The main waste water constituents, which are at the same time the major plant nutrient elements, can be utilized in agricultural crop production. Using experimentally determined relative efficiency indices for different elements and crops, the availability of nutrients and accordingly the nutrient supply at different applications can be calculated. Doses can be adjusted to plant nutrient requirements according to different criteria. Optimum adjustment leads to an average dose of $25 \mathrm{~mm}$ per year at the normal cropping pattern of the Peat Colonies. If excess supply is accepted this average value can be increased to $60 \mathrm{~mm}$ without harmful effects. At higher doses decreases in yield and/or quality have to be expected.

The relationships between nutrient supply and crop yields take a key position in the calculation of farm economic results. Change in labour income of the farmer offers a good means to express the effect of waste water utilization. Doses of 50 to $100 \mathrm{~mm}$ per year will increase labour income with about 100 guilders per ha.

\section{References}

Anonymous, 1972. Landbouwkundig gebruik van afvalwater uit de aardappelmeelindustrie. Rapport Werkgroep TNO voor Onderzoek Irrigatie Afvalwater Aardappelmeelfabrieken.

Baars, C., 1972. Rapport omtrent de technische en financiële aspecten van het verregenen van afvalwater van de aardappelmeelindustrie. Afd. Weg- en Waterbouwkunde en Irrigatie, Landbouwhogeschool, Wageningen

Haan, F. A. M. de, 1972. Resultaten van belasting van de bodem met grote hoeveelheden afvalstoffen. Nota Inst. CultTech. Waterhuish. 657.

Haan, F. A. M. de \& J. Beuving, 1972. Zuivering van proceswater uit de aardappelmeelindustrie door beregening op landbouwgrond. Nota Inst. CultTech. Waterhuish. 693.

Hoogeveen, G. J., 1972. Bedrijfseconomische gevolgen van het gebruik van afvalwater van de aardappelmeelindustrie voor het veenkoloniale landbouwbedrijf. Nota culttech. Dienst.

Kortleven, J., 1968. Een onderzoek naar de mogelijkheid van het gebruik van vruchtwater van de aardappelmeelindustrie als meststof. Rapp. Inst. Bodemvruchtbaarheid 68-2.

Kronenberg, M. E., 1972. Behandeling van veenkoloniaal afvalwater. Landbouwk. Tijdschr. 84 (11): 388-394.

Reinds, G. H., 1971. Verslag van de berekening van de kosten-baten verhouding van een aantal kavelinrichtingsalternatieven in de Veenkoloniën. Nota Inst. CulTech. Waterhuish. 644.

Riem Vis, F. 1971a. Maximaal toelaatbare hoeveelheden vruchtwater van aardappelmeelfabrieken uit een oogpunt van mineralenvoorziening. Rapp. Inst. Bodemvruchtbaarheid 71-1-8 (100).

Riem Vis, F. 1971b. De zuivering van afvalwater van aardappelmeelfabrieken door middel van beregening van landbouwgronden. Rapp. Inst. Bodemvruchtbaarheid C 7975. 